\title{
The Role of Built Environment in Collective Learning: The Case of Rumah Sahabat Salman
}

\author{
${ }^{1}$ AGUS S. EKOMADYO, ${ }^{2}$ ANDHIKA RIYADI, ${ }^{3}$ SALIM RUSLI, ${ }^{4}$ RAKHMAT F. ADITRA \\ 1,2,4 School of Architecture, Planning and Policy Development, Institut Teknologi Bandung, Bandung, Indonesia, \\ ${ }^{3}$ Research and Publication Division Salman Mosque Foundation, Bandung, Indonesia, \\ email: ${ }^{1}$ ekomadyo00@gmail.com; ${ }^{2}$ riyadiandhika@gmail.com; \\ ${ }^{4}$ salim.rusli@salmanitb.com; ${ }^{4}$ rakhamt.aditra@gmail.com
}

\begin{abstract}
The built environment relates to the important value of an environment as part of the learning process. Collective learning refers to the process of knowledge creation that continue through the association movement among human actors and technical object. By taking the case of Rumah Sahabat (RuSa) program, this paper maps and identifies the role of built environment in collective learning using Actor-Network Theory (ANT) approach. RuSa is a program of Salman ITB mosque to train students as cadres by facilitating them rent houses in the nearby settlement. Students, in turn, have to serve and deliver Islamic values to the local communities. The assembly of RuSa program is mapped into three moments: RuSa trainees teach Quran to the children in the local mosque; children bring home the homework and discuss them with their parents; RuSa trainees and local citizens developed the "Reading Terrace" in community main hall. The research result shows that the socio-technical approach can guide the development of built environment to improve and sustain the learning since it depends on human and non-human actors involved.
\end{abstract}

Keywords: built environment, collective learning, rumah sahabat salman

\section{Introduction}

The built environment concept emerges along with the awareness that the built forms are strongly related to the environment. Regions, cities, districts, buildings, streets, and fixtures are regarded by their relation to social and natural environment. This term is often correlated with natural environment, so that built environment is a discourse the man-made to make a better environment. It can be defined as everything humanly made, arranged, or maintained to fulfill human purposes to mediate the overall environment with result that affect the environmental context. It includes fixtures, equipment, buildings, districts, cities, or regions (Batruska, 2007:5-8). Here, built environment frames human activities for selfdevelopment, including learning.
The built environment is related to learning when the environment is recognized as important things in a learning process. In social learning, the environment is important as a reciprocal factor of human cognition for the behavioral change (Bandura, 1977:vii). In social learning, built environment frames knowledge creation for cognition and behavioral change by the interaction between human and the environment. Built environment can frame the social learning process when community builds the common purpose and shared values to reach their goal together (Bickford and Wright, 2006:39). It is also important to develop learning strategies in practice because it has a role as space for people to explore, collaborate, and discuss things together (Oblinger, 2006:1).

In social constructivism, learning is understood not only for human cognition

Received: 2019-06-20, Revised: 2019-10-28, Accepted: 2019-12-27

Print ISSN: 0215-8175; Online ISSN: 2303-2499. DOI: https://doi.org/10.29313/mimbar.v35i2.4811

Accredited Sinta 2 based on the decree No.10/E/KPT/2019 until 2024. Indexed by DOAJ, Sinta, Garuda, Crossreff, Dimensions 
and behaviour changes, but more as processes, practices, and interactions through which knowledge is created, contested, and transformed, and how perception emerges and changes. (McFarlane, 2011:3). Learning is not only as a way of knowing and understanding the world but rather as a way of actively constructing and being in the world. Through learning, knowledge is positioned in space and time, constructed, and continued by mediation among interaction of human and technical objects (Higgins, 2010:193201). There are several pattern of how social activities influence individual learning, such as active social mediation of individual learning, social mediation as participatory knowledge construction, social mediation by cultural scaffolding, the social entity as a learning system, learning to be a social learner, and learning social content (Salomon and Perkins, D.N. (1998,3-6).

A socio-technical approach that has been developed in Actor-Network Theory domain focuses more on disentangle the social by tracing the translation among human and technical objects. This approach is developed to see the flat relation between human and technical objects, or actors and artefacts, considering that the technology, a set of technical competences, is shaped by the societies. By a socio-technical approach, social construction can be unraveled through calculating the relation between actors and tracing these associations by suspending or resuming them. ANT's socio-technical approach introduces the term collective which refers to something that is collected, to describe the social process by mapping the movement of human and non-human association.

In a collective perspective, learning is about to feel the way to understand and construct the world through the combined action of human and non-human actors. (McFarlane,2011:3). Non-human actors are put as a part of the collective action of human actors involved in knowledge transferring. Here, non-human can substitute, mediate, and communicate human actors (Rice, 2017:1-20). In social learning, the role of technology is to help human actors to calculate their decision-making (Ellison \& Fudenberg, 1993:1) and to shape the social context of learning (Buckingham Shum \& Fergusson, 2012: 3-26, Fergusson \& Buckingham Shum, 2012:1-12).

Through Rumah Sahabat (RuSa)
Salman ITB, this paper exercise the sociotechnical approach of collective learning. By this approach, learning process is traced and unravels the way knowledge is transferred among human actors mediated by non-human actors. Thus, the role of built environment, as non-human actors, can be identified in the learning process by mapping their translation among human actors.

Rumah Sahabat (RuSa), means "the House of Companion", is a part of Salman Mosque ITB program of cadres formation for the students. It is stated that the mosque develops a mission "to become an independent campus mosque, a pioneer on establishing the Islamic civilization" (Rusli, 2017). By cadres formation programs, several students are prepared and trained to exercise their capability to lead and serve communities and to disseminate Islamic values developed by Salman Mosque. This program is a kind of social learning of leadership where the learner can develop self-management of leadership (Manz and Sims Jr., 1980:361-367) and understand the ethical values of leadership activities (Brown, et al., 2005: 117-134).

Actually, Rusa program provides rent houses like dormitories for several students from various universities in Bandung which are located at the vicinity of Salman mosque. This program is a replication of Salman Dormitory where students are assigned to serve communities inside the mosque (jama'ah); whereas, students of RuSa have tasks to diseminate Islamic values teaching from the mosque to the nearby communities. The location is chosen by considering the local community mosque as a medium to transfer Salman values from RuSa to the local communities. There are two rent houses -located at Kebon Bibit settlement in Bandung- used for this program: one for male students and another one for femele students where each can accommodate 10 students or less. By reflecting on their experiences, the RuSa trainees are expected to learn and have adequate capabilities to become future leaders who will internalize the Salman values, especially vision of Islamic civilization, to larger societies (Riyadi et al., 2017).

This research traces the learning process of RuSA from the early ideas in Salman Mosque to the achievement of RuSa trainees for local community development. In practice, RuSa trainees develop many strategies to make a relationship with local citizens to disseminate Islamic values and 
Salman mosque vision. The role of built environment in this strategy becomes the main focus of this research.

This research is conducted in order to understand the role of built environment in collective learning through the case of RuSa program with the objectives as follows: 1) to map important moments in learning process of RuSa as collective learning and how knowledge is transferred among actors, 2 ) to describe human and non-human actors relation in each moment, especially to identify the built environment position as mediator of learning process, and 3) to formulate the role of built environment as non-human actors in this collective learning.

\section{Research Methodology}

This research is conducted using ActorNetwork Theory (ANT), the theory in which the term collective is derived. The term collective is used to explain the movement of social ties as an association of human and non-human actors that can be suspended or resumed (Latour, 2005:247). The collective can be mapped through how actors create networks, which called translation, that happen at four non-linear processes: problematization, interest, enrollment, and mobilization (Callon,1986:196-223). A socio-technical approach that explains relational built environment has already exercised by mapping the translation among actors and artefacts and is regarded to give a more accountable description for a social construction of place (Ekomadyo, et al., 2017a, Ekomadyo, et al., 2017b, Ekomadyo and Yuliar, 2014). Here, the social is called a collective which refers to things being collected as associations of human and nonhuman actors that moved continuously and can be suspended or resumed. Collective happens through translation, where human and non-human built network with each other (Latour, 2005: 247, Callon,1986:196-223).

Through this approach, the research is focused to map the translation moments of RuSa learning activities with communities, starting from the early ideas of Salman Mosque program of cadres formation to RuSa achievement to engage local communities for Islamic learning. The map is drawn by sociotechnogram graphic to identify the relationship between human and non-human actors in each translation moment. This sociotechnogram can identify the position of built environment as non-human actors.
This research focus to observe the role of built environment as mediators' knowledge transfers among human actors.

This research is organized in several stages: 1) identifying the RuSa programs related to the Salman Mosque vision as campus mosque, 2) identifying RuSa trainees activities in practice and their relationship with local communities, 3) mapping the important moments of RuSa activities to develop network with local people to disseminate the Islamic values, 4) mapping the relationship between human and non-human actors in each moment and finding out how knowledge is transferred among these relationships, 5) identifying the position of built environment as non-human actors and collective learning mediators, and 6) formulating the role of built environment in RuSa collective learning with local communities.

Data is gathered through observation of built environment and interview with RuSa participants: trainees, facilitators, and nearby community. The interview is conducted by a qualitative approach, guided by ethnographybased inquiry to understanding how learning process happens, what kind of knowledge and values are transferred, and how the built environment helps the learning activities. The aspects being observed and interviewed are the relation among RuSa and local communities, what kind of activities, and where these are taken places.

\section{Results and Discussion}

\section{Learning Space at Salman Mosque and Program of RuSA}

Salman Mosque was the first campus mosque to build in a secular university in Indonesia. Located at Institut Teknologi Bandung (ITB), this mosque was built in 1970 as manifestation of Muslim community who struggled to gain an appropriate place for Friday praying. The Salman mosque has become as a symbol of unity of Muslim community in this university until now. Mosque architecture was influenced by rational design of Modernism that signified intellectual identity in socio-religious activities in this mosque (Holik \& Aryanti, 2017:5, Ekomadyo, 2011:112-113).

As campus mosque, Salman mosque is not only a place for worship, but also for Islamic learning, especially for ITB Muslim students the nearby campuses. Students' 
socio-religious activities enrich the mosque atmosphere, so that they are called Salman activists. Simple character of mosque architecture make it easier for the community to build attachment with this mosque (Dewiyanti \& Faisal, 2016:58). Various temporal activities, such are discussion and events, are located on mosque terraces and courtyards. Some activities are then being formalized into the activity of units and provided special rooms near the mosque main building.

Special facilities for several Salman activists are dormitories. Here, selected activists are subsidized to live here and get task to serve daily activities of Salman community. The dormitories are like a "vessel" to deliver Islamic values from Salman mosque to the community and also prepare the dormitory members to apply these values in daily community problems.

Having been organized for several years, it is recognized that the dormitory system gives the activists a special experience while they were serving the mosque communities. They got brotherhood spirit among other activists, living together to help and serve mosque activities. Many kinds of assignments and activities actually increased their personal capabilities such as leadership, managerial skills, communication, social skill, and others.

The benefit of dormitory system is that RuSa program was initiated to enlarge the learning and serving scope in the vicinity of Salman Mosque. In the beginning, this program was aimed to disseminate Islamic values of Mosque Salman to nearby communities through RuSa trainees. Along the time, this program has been evaluated and put more forming cadres orientation to give special experiences to students when they interact with local communities. It is recognized that if the interaction going fluently, the dissemination can happen naturally.

Living in the local community, the RuSa trainees involve in various community activities. Every morning, they attend routine activities in the mosque, such as Quran reciting, Arabic language learning, and mosque cleaning. Seasonal activities such as Islamic courses for the community, religious festival such as Ramadhan festival and Idul Adha celebration, and also other social activities strengthen the relationship between RuSa trainees and local citizens. By having a good relationship, RuSa trainees get the local citizens' trust to give their children Quran and academic tutorial in the mosque.

Evaluating the program, the Salman ITB Mosque Institution expects the RuSa program not to only empower the local community, but rather give learning experiences for the trainees while working with local communities. The RuSa trainees are expected to raise their social skills such as improving communication skills, earning trust and sympathy from the community, negotiate their values and plans, or dealing with internal and external conflict. They are also expected to learn certain attitudes such as humility, empathy, and openness, as important provisions for leaders to come (Figure 1).

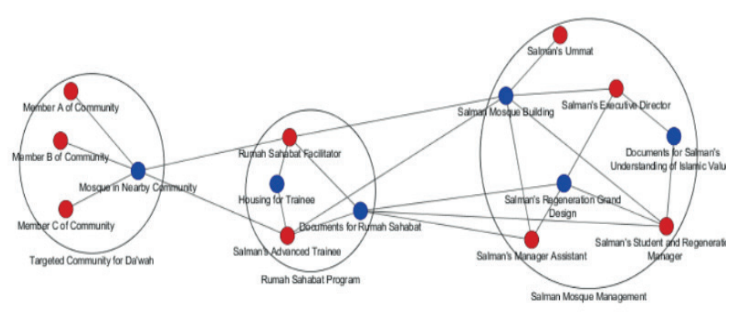

Figure 1. The Target Concept of RuSa program: from Salman Mosque to the targeted community (Riyadi et al., 2017).

\section{Collective Learning Moments of Rumah Sahabat Salman}

The assembly of RuSa program and local community activities is mapped into three important moments. First, when RuSa trainees started to stay in the rented houses, prayed together daily in the nearby local mosque, and then taught the children to read The Quran in this mosque. Second, when RuSa trainees gave homework to the children who then talked to their parents so that their learning activities were recognized by local citizens. Third, when RuSa trainees and local citizens created the "Reading Terrace" in order to expand reading Quran learning for the children and develop the reading habit for the citizen (Riyadi et al., 2017).

The first step that RuSa trainees should do is to make engagement with the local community. Living daily in rented houses made it easier for the trainees to join communal praying in the local mosque (al Arif mosque) and create a good relationship with citizen including the children. Teaching activities also involved the local mosque management in arranging the time of learning, that is every evening after the children had finished their school in the morning and done playtime in the afternoon (Figure 2). The parents also 
gave a positive response to these activities because the children can improve their knowledge and get better activities rather than playing all day long.

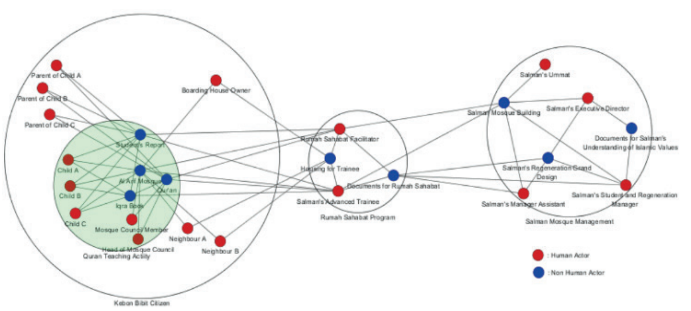

Figure 2. Moment of The Quran teaching for Children in Local Mosque by RuSa trainees (Riyadi et al., 2017).

The next important moment happened when RuSa trainee gave homework to the children. They showed and talked about that homework to their parents and the parents really appreciated their learning activities at the mosque. This information then being spread out to another citizen in Kebon Bibit settlement, so that the RuSa program will be more recognized by the local citizen. Citizen appreciation opened a discussion for developing learning activities which involved university students and local citizen (Figure 3).

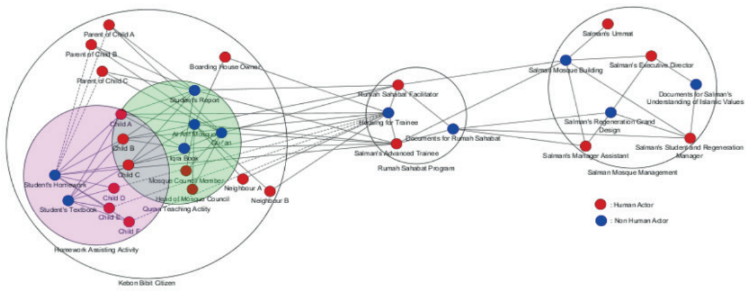

Figure 3. The Expansion of RuSa program: from Local Mosque to Citizen's Houses (Riyadi et al., 2017).

Here, beside RuSa houses and a local mosque (al Arif), the parents' houses and Kebon Bibit settlement played a significant role in network enlarging in collective learning. The expansion of RuSa program to the local community was mediated by human actors (children and parents) and nonhuman actors (homework, children's houses). Other technical objects, such as Kebon Bibit settlement, also mediated the communication among parents which then constructing an appreciation to the RuSa activities.

An important moment for intensive engagement happened where RuSa trainee and local citizen built the "Reading Terrace" program together. This program was expected to enhance local citizen habit of reading the books provided by RuSa trainees collected from Salman community donation. At the start, this activity was only targeted to the children, but there were also adults who joined this program to borrow some interesting books. The location of "Reading Terrace" was chosen at the local community hall, not in $\mathrm{Al}$ Arif mosque due to these two reasons: it has suitable large for gathering community and the security of book lending management. The community main hall was also used as a Reading Terrace open ceremony that signified the engagement of its members (Figure 4).

The reading terrace which referred to both the place and activities indicated that the terrace of the community main hall was an important built environment in this collective. The community hall was a significant node in network enlarging between RuSa program and Kebon Bibit citizen. In this place, local citizen learned from the books (artefacts) and RuSa trainees (human actors) about any knowledge, especially Islamic knowledge. In the same place, RuSa trainees also learned to deliver Islamic values or "dakwah" as a non-linear process. Through various actors and artefacts, including built environment, "dakwah" is a non-linear process of delivering Islamic values through any kind of translation.

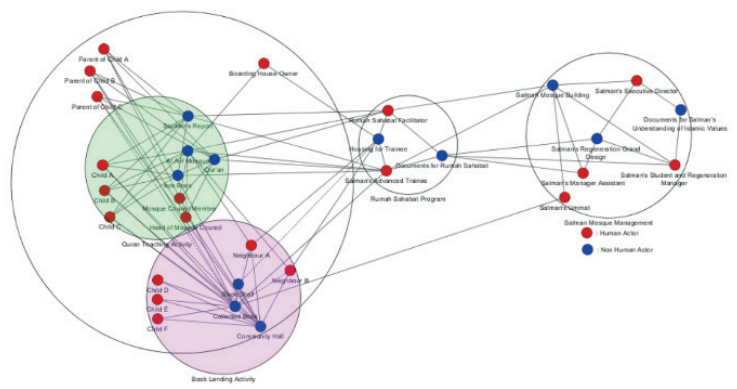

Figure 4. Community engagement through "Reading Terrace" Program (Riyadi et al., 2017).

Those three significant moments have reflected network enlargement in RuSa learning activities, starting by students living as trainees in the local settlement until the engagement of local citizen to build community learning activities together. As a place aimed for Islamic activities, the mosque played an important role as symbol of spreading Islamic values. However, this case research tells us that another built environment can also mediate that. In RuSa case, local mosque, rented houses for RuSa trainees, children houses, community main hall, and Kebon Bibit settlement played a significant role in collective learning. Through tracing 
the moments above, social construction in learning activities can be unraveled and the role of built environment as artefact can be mapped and identified.

\section{The Role of Built Environment of RuSa Collective Learning}

By tracing the collective of RuSa assemblies with local community in each moment, the position and the role of built environment can be identified sequentially. The Salman mosque plays a significant role since it is an institution where the idea is derived; it also represents an identity of the campus mosque with a vision to build Islamic civilization. Many activities create "peripheral spaces" beside main hall for worship in Salman mosques, one of them is a dormitory. The concept of dormitory is expanded to nearby Mosque complex, facilitating rented house for trainees to disseminate Islamic values to local mosques; this program is called RuSa (Rumah Sahabat=A Friend's House). Initializing from RuSa's houses, the trainees enhance to utilize the nearest mosque, Al Arif, to start and continue their Islamic activities, including teaching the Quran to the children. Here, the trainee interacts with the local citizen so that they are known as students who often have activities in the local mosque. Children tell their parents about their activities which, in turn, gradually attracts their parents'attention and other local citizens to join RuSa learning. The achievement of collective learning gets the moment in "reading terrace" taken place at the community main hall since there are not enough appropriate spaces inside Al Arif mosque for reading activities of the communities.

By applying a collective approach, the role of built environment and its relationship with others are described sequentially. The association movement in collective learning can be traced through step-by-step of the learning process, identified which actors involved as well as their relationship and the position of non-human actors including the built environment. From a social learning perspective, the built environment is seen only as a setting for social interaction, but the socio-technical perspective sees it as a mediator for learning, of how it is utilized by human actors to transfers knowledge sequentially. In the case of RuSa, it is found there are several roles of the built environment that mediating the learning process. Salman mosque managers used dormitory model of rented house to disseminate Islamic values to nearby communities through RuSa trainees. RuSa trainees consult their work with the facilitators in Salman mosque and coordinate with other members to develop mode for the interaction with local communities in their rented house. RuSa trainees used local mosque to disseminate Islamic values to the children, and children used their houses to introduce RuSa learning to their parents. When local communities are interested and decide to join RuSa learning activities, they chose community main hall to create "reading terrace" since there is no appropriate space inside the local mosque.

This research also found that mosques play a significant role in Islamic learning. Islamic values are developed in Salman mosque which then delivered to the nearby communities mediated by local mosque. But, the relationship with those mosques does not happen just like that: there are several non-human actors mediated them. If Salman mosque has peripheral spaces to support its activities including learning, the local mosque used another built environment, which is a community main hall, to give more appropriate spaces for local communities to learn Islamic values delivered by RuSa trainees. From the ANT's perspective, the built environment, non-human actors that mediated the actors' relationship, is called intermediaries (Latour, 2005:37). It can be concluded that mosques play an important role in Islamic learning and transferring knowledge to the communities with the condition that there are a lot of intermediary spaces.

\section{Conclusions}

By tracing the translation of RuSa program at Kebon Bibit settlement, this research can map and identify the role of built environment in collective learning. Rented houses for the trainees, local mosque, children's houses, Kebon Bibit settlement, and community main hall play a significant role sequentially in important moments of the assembly between RuSa program and local community. Collective learning traced how Islamic values are delivered, transferred, and constructed, as well as how built environment mediates the interaction along the process. As a center of Islamic learning activities, the mosque plays an important role as a symbol of the unity of Muslim community. Nevertheless, this research shows that the role of mosque peripheral spaces or other built environments outside the mosque is also 
important in collective learning. Salman ITB mosque complex, mosque main hall, terraces, courtyard, activity unit rooms, and dormitory are places where the activists constructing Islamic values in socio-religious activity practices. In RuSa case, trainees' rented house, local mosque, children houses, local settlements, and local community's main hall can be described sequentially as mediated built environments in the collective learning process.

If Salman Mosque complex is welldesigned and supported by campus intellectualism and professionalism, the RuSa's learning spaces are mostly informally designed. Learning spaces are designed tactically by RuSa trainees and local citizen adjusting the constraint and optimizing the practical condition. Collectively, communal learning space design is an opportunity for architectural design to promote more effective learning spaces. Interpreting the translation of RuSa learning process, learning space design should consider, calculate, and predict the socio-technical relation.

From a socio-technical perspective, the role of the built environment to guide a better-built form in the future is relational; it is positioned by translation among actors and other artefacts.

\section{Acknowledgments}

The researchers would like to thank the Salman ITB Mosque Institution for research funding and RuSa trainees and facilitators to give important data for the research. We would also thank Sonny Yuliar, a lecturer at Development Studies Program ITB, for an interesting discussion about socio-technical approach for collective learning.

\section{Author's Note}

The author declares that there is no conflict of interest regarding the publication of this article. Authors confirmed that the data and the paper are free of plagiarism.

\section{References}

Bandura, A. (1977). Social Learning Theory. Prentice-Hall, New Jersey.

Batruska, T.J. (2007). The Built Environment: Definition and Scope. In McClure, W., and Bartuska, T.J, (2007). The Built
Environment: A Collaborative Inquiry into Design and Planning. John Wiley \& Sons, Inc., Hoboken, New Jersey.

Bickford, D.J., and Wright, D.J. (2006). Community: The Hidden Context for Learning. In Oblinger, D.G (ed). Learning Spaces. Educause e-book.

Brown, M.E., Trevino, L.K., Harrison, D.A. (2005). Ethical Leadership: A Social Learning Perspective For Construct Development And Testing. Organizational Behavior And Human Decision Processes, 97 (2005) 117-134. doi:10.1016/J. Obhdp.2005.03.002

Buckingham Shum, S., \& Ferguson, R. (2012). Social Learning Analytics. Educational Technology \& Society, 15 (3), 3-26.

Callon, M. (1986). Some elements of a sociology of translation: domestication of the scallops and the fishermen of St Brieuc Bay. In, J., Power, action and belief: a new sociology of knowledge? Routledge, London.

Dewiyanti, D., and Faisal, B. (2016). Deciphering the Language of Space at the Salman Mosque, Bandung, Indonesia through the Multi-Sensory Approach. International Journal of Engineering Research and Development, e-ISSN: 2278-067X, p-ISSN: 2278-800X, , Volume 12, Issue 2 (February 2016).

Ekomadyo, A.S., Santri, T., Riyadi, A. (2017a). Reassembling Traditionality and Creativity? A Study of Creative Community Movement in Cihapit Market Bandung. Int'l Conference of Architectural Education in Asia (Eduarchsia), Indonesian Islamic University, Yogyakarta, November 9, 2017, https://doi.org/10.1051/ shsconf/20184107006

Ekomadyo, A.S., Santri, T., Riyadi, A. (2017b). Habitat for Innovative Milieu: A PlaceMaking Study of University and Start-up Enterprises Relationship. HABITechno International Seminar - Ecoregion as a Verb of Settlement Technology and Development for Sustainable Urbanization. Institut Teknologi Bandung, Doi : 10.1088/1755-1315/152/1/012020

Ekomadyo, A.S., dan Yuliar, S. (2014). Social Reassembling as Design Strategies". $5^{\text {th }}$ Arte- polis International Conference and Workshop - Reflections on Creativity: Public Engagement and The Making of Place. Science Direct - Procedia - Social and Behavioral Sciences 184 (2015) 152 $160,1877-0428$ (c) 2015, doi: 10.1016/j. sbspro.2015.05.075

Ekomadyo, A.S. (2011). Architectural 
Representation of Islamic Modernism in Indonesia, Case Study: Architecture of Achmad Noeman. Nakhara Journal of Environmental Design and Planning. Number 7, October 2011. Faculty of Architecture, Chulalongkorn University Bangkok.

Ellison, G., and Fudenberg, D. (1993). Rules of Thumb for Social Learning. Journal of Political Economy, 101 (4).

Ferguson, R., and Buckingham Shum, S. 2012). Social Learning Analytics: Five Approaches. 2nd International Conference On Learning Analytics \& Knowledge, Vancouver, Canada, Pp. 23-33. http://dx.doi.org/ doi: $10.1145 / 2330601.2330616$

Higgins, D., Mirza, M., (2010). Learning in and through work practices: mediational artefacts as a process of social learning in the knowledge-based small firm. Int. J. Innovation and Learning, Vol. 8, No. 2, 2010 189, Inderscience Enterprises.

Holik, A.A.R., and Aryanti, T. (2017). The Salman Mosque: Achmad Noe'man's Critique of Indonesian Conventional Mosque Architecture. 1st Annual Applied Science and Engineering Conference. IOP Conf. Series: Materials Science and Engineering. 180 (2017) 012090. doi:10.1088/1757-899X/180/1/012090.

Latour, B. (2005). Reassembling the Social: an Introduction to Actor-Network Theory. New York: Oxford University Press.

Manz, C.C., and Sims Jr., H.P. (1980). Self-Management as a Substitute for Leadership: A Social Learning Theory
Perspective. The Academy of Management Review, 5 (03), July 1980, 361-367. doi: 10.5465/AMR.1980.4288845

McClure, W., and Bartuska, T.J. (2007). The Built Environment: A Collaborative Inquiry into Design and Planning. John Wiley \& Sons, Inc., Hoboken, New Jersey

McFarlane, C. (2011). Learning the City Knowledge and Translocal Assemblage. Blackwell Publishing, West Sussex.

Oblinger, D.G. (2006). Space as a Change Agent. In Oblinger, D.G. (ed.), Learning Spaces. Educause e-book.

Oblinger, D.G. (ed.) (2006). Learning Spaces. Educause e-book.

Rice, L., (2017). Nonhumans in participatory design, CoDesign: International Journal of CoCreation in Design and the Arts, DOI: 10.1080/15710882.2017.1316409

Riyadi, A., Ekomadyo, A.S. Rusli, S., Nuzzela, S., Yuliar, S. (2017). Local Wisdom for Social Learning: Case of Rumah Sahabat Salman. HABITechno International Seminar - Ecoregion as a Verb of Settlement Technology and Development for Sustainable Urbanization. Institut Teknologi Bandung, November 11, 2017.

Rusli, S. (2017). Program Teknologi Salman: Memberdayakan Masyarakat Secara Terpadu. Pikiran Rakyat. Bandung, 13 Maret 2017

Salomon, G., and Perkins, D.N. (1998). Chapter 1: Individual and Social Aspects of Learning. Review of Research in Education, 23 (1). doi: 10.3102/0091732x023001001 